\title{
Sintesis dan Karakterisai Kitosan dari Limbah Cangkang Udang Sebagai Stabilizer Terhadap Ag Nanopartikel
}

\author{
Astuti Amin*, Nur Khairi, Eko Kulla Allo \\ Sekolah Tinggi Ilmu Farmasi Makassar, Makassar, 90241, Indonesia
}

\begin{tabular}{l} 
I N F O A R T I K E L \\
\hline Diterima 06 Oktober 2019 \\
Disetujui 27 Oktober 2019 \\
\hline Key word: \\
Shrimp shell, \\
chitosan, \\
silver nanoparticles \\
\hline Kata kunci: \\
Kulit udang, \\
kitosan, \\
nanopartikel perak
\end{tabular}

*e-mail:amin.astuti@gmail.com
${ }^{*}$ Telp:085255350652

\begin{abstract}
A B STRACT
The research of manufacturing chitosan from shrimp shell waste, and their use as a stabilizer in the manufacture of silver nanoparticles has been done. The aim of the research was to synthesize silver nanoparticles using chitosan as a stabilizer by chemical reduction method and determine the effect of chitosan concentration on the stability of Ag nanoparticles. In this study, the raw material used is shrimp shell powder and then processed in several stages, eliminating proteins, demineralization, and deacetylation. Chitosan obtained is $16.4 \%$ of shrimp shell powder, with a degree of deacetylation of $85 \%$. Chitosan is used to synthesize silver nanoparticles as a reducing agent of silver ions in silver nitrate solution and is expected to be stabilizer. Sample containing $45 \mathrm{mg}$ of chitosan and $1000 \mathrm{ppm}$ AgNO3 has 421,60 $\mathrm{nm}$ of maximum wavelength, and the average particle size is $154.07 \mathrm{~nm}$.
\end{abstract}

\begin{abstract}
A B STRAK
Telah dilakukan penelitian pembuatan kitosan dari cangkang udang, dan pemanfaatannya sebagai penstabil dalam pembuatan nanopartikel perak. Tujuan dari penelitian adalah untuk mensintesis nanopartikel perak menggunakan kitosan sebagai stabilizer dengan metode reduksi kimia dan menentukan pengaruh konsentrasi kitosan terhadap kestabilan Ag nanopartikel. Pada penelitian ini, bahan baku yang digunakan adalah serbuk cangkang udang kemudian diproses dengan beberapa tahap yaitu deproteinasi, demineralisasi, dan deasetilasi. Rendamen kitosan yang diperoleh adalah 16,4\% dengan derajat deasetilasi 85\%. Kitosan digunakan untuk mensintesis nanopartikel perak sebagai reduktor terhadap ion perak dalam larutan perak nitrat dan diharapkan untuk menjadi penstabil. Sampel yang mengandung $45 \mathrm{mg}$ kitosan dan 1000 ppm $\mathrm{AgNO}_{3}$ memiliki panjang gelombang maksimum 421,60 nm, dan ukuran partikel rata-rata yaitu 154,07 nm.
\end{abstract}

\section{Pendahuluan}

Sampai saat ini, udang windu masih menjadi komoditas perikanan yang memiliki peluang usaha cukup baik karena sangat digemari konsumen domestik dan konsumen dalam negeri. Ketertarikan konsumen terhadap udang windu tidak sebatas pada rasa dagingnya yang lezat. Limbah dari bagian tubuh udang windu juga menjadi daya tarik tersendiri. Bagian kepala dan cangkangnya (carapace) bisa memberi nilai tambah yang cukup berarti. Limbah kulit udang ini bisa dimanfaatkan sebagai bahan baku berbagai industri, seperti industri farmasi, kosmetika, pangan, dan tekstil. Salah satu kandungan kulit udang yang bisa dimanfaatkan sebagai bahan baku industri adalah chitin dan chitosan (senyawa turunan dari chitin) [1].

Kitosan merupakan biopolimer alam, berbentuk polisakarida linier yang tersusun atas B-(1-4)-linked D-glucosamine dan N-acetylD-glucosamine dengan distribusi acak. Kitosan 
diproduksi melalui proses deasetilasi senyawa kitin, yakni komponen utama pada cangkang binatang crustaceae seperti rajungan dan udang. Dewasa ini kitosan telah banyak diaplikasikan secara komersiil pada industri kimia, pangan dan farmasi. Sebagai carrier obat, kitosan telah dikembangkan dalam berbagai bentuk sediaan farmasi, seperti tablet, bead, microsphere dan nanopartikel.

Nanoscience adalah ilmu yang mempelajari fenomena khususnya pada benda yang berukuran 1 sampai beberapa ribu nanometer $\left(10^{-9} \mathrm{~m}\right)$. Kata nano berasal dari bahasa Yunani yang berarti kerdil. Skala nano adalah ukuran yang satu miliar kali lebih kecil dari meter $\left(10^{-9} \mathrm{~m}\right)$. Nanoteknologi adalah istilah umum yang merujuk kepada teknik dan metode untuk mempelajari, mendesain, dan fabrikasi alat, pada tingkatan atom dan molekul $[2,3]$.

Nanopartikel adalah kelompok khusus bahan dengan fitur unik dan aplikasi yang luas dalam berbagai bidang. Nanopartikel logam, seperti yang mengandung emas dan perak telah dikenali pentingnya dalam bidang kimia, fisika, dan biologi karena sifat optik, elektrik, dan fototermalnya yang unik. Kemudahan sintesis nanopartikel emas dan perak dan afinitasnya untuk mengikat banyak molekul biologis membuat nanopartikel ini menarik untuk dipelajari. Berbagai metode fisik dan kimia telah dilaporkan selama dua dekade terakhir untuk sintesis nanopartikel perak, yaitu melalui pendekatan kimia, yang paling banyak digunakan seperti reduksi kimia, teknik elektrokimia, dan reduksi fotokimia. Metode yang paling populer adalah reduksi kimia terhadap garam perak dengan adanya stabilizer. Yang paling sering digunakan sebagai agen penstabil adalah polimer dan surfaktan [4].

Kemunculan nanoscience dan nanoteknologi memberikan kesempatan untuk lebih menjelajahi efek bakterisida dari nanopartikel logam. Efek bakterisida dari nanopartikel logam dikaitkan dengan ukurannya yang kecil dan luas permukaannya yang besar, yang membuatnya lebih dapat berinteraksi secara dekat dengan membran mikroorganisme, dan bukan semata pada kemampuannya untuk melepaskan ion logam dalam larutan [5]. Telah dilaporkan bahwa nanopartikel perak bersifat non toksik kepada manusia dan sangat efektif melawan bakteri, virus, dan mikroorganisme eukariotik lainnya pada konsentrasi rendah tanpa danya efek samping. Pada konsentrasi yang kecil, perak aman untuk sel-sel manusia namun bersifat mematikan untuk bakteri [6].

Dewasa ini, nanopartikel logam dengan ukuran nano dan seragam telah diselidiki secara intensif karena aplikasinya dalam bidang optik, elektronik, peralatan magnetik, sebagai katalis, dan adsorben. Kelompok amina pada kitosan merupakan basa Lewis untuk ion-ion logam dan berfungsi menyebarkan ion-ion tersebut dalam matriks kitosan [7]. Diharapkan dengan penambahan kitosan, dapat terjadi reduksi terhadap ion perak menjadi nanopartikel perak. Kitosan juga diharapkan dapat membantu produk untuk mencapai keseragaman ukuran dalam skala nanometer. Oleh karena itu diperlukan karakterisasi terhadap nanopartikel perak (Ag nanopartikel) yang telah dibuat, salah satunya dari segi ukuran

\section{Bahan dan Metode}

Bahan yang digunakan dalam penelitian ini adalah $\mathrm{NaOH}, \mathrm{HCl}$, aquadest, $\mathrm{AgNO}_{3}$ padatan, kitosan (sumber cangkang udang).

Alat yang digunakan dalam penelitian ini adalah alat-alat gelas, oven, pengaduk magnetik (HEALTH, Cina), timbangan analitik (Mettler Toledo), spektrofotometer UV-VIS (Shimadzu, Jepang), instrumen Fourier Transform Infrared Spectroscopy (Shimadzu, Jepang), Scanning Electron Microscope (SEM), alat freeze dryer, dan Particle Size Analyzer (PSA)

\section{Deproteinasi}

Proses ini dilakukan pada suhu $60-70^{\circ} \mathrm{C}$ dengan menggunakan larutan $\mathrm{NaOH} 1 \mathrm{M}$ dengan perbandingan serbuk udang dengan $\mathrm{NaOH}=1: 10$ (gr serbuk/ml NaOH) sambil diaduk selama 60 menit. Kemudian campuran dipisahkan dengan disaring untuk diambil endapannya.

\section{Demineralisasi}

Penghilangan mineral dilakukan pada suhu $25-30^{\circ} \mathrm{C}$ dengan menggunakan larutan 
$\mathrm{HCl} 1 \mathrm{M}$ dengan perbandingan sampel dengan larutan $\mathrm{HCl}=1: 10$ (gr serbuk $/ \mathrm{ml} \mathrm{HCl}$ ) sambil diaduk selama 120 menit. Kemudian disaring untuk diambil endapannya.

\section{Deasetilasi Kitin menjadi Kitosan}

Kitin yang telah dihasilkan pada proses diatas dimasukkan dalam larutan $\mathrm{NaOH}$ dengan konsentrasi 50\% (berat) pada suhu 90$100^{\circ} \mathrm{C}$ sambil diaduk dengan kecepatan konstan selama 60 menit. Hasilnya disaring, endapan dicuci dengan aquadest lalu ditambah larutan $\mathrm{HCl}$ encer agar $\mathrm{pH}$ netral kemudian dikeringkan. Maka terbentuklah kitosan. Selanjutnya kitosan yang diperoleh dianalisis dengan menggunakan metode FTIR untuk mengetahui Derajat Deasetilasi (DD) [8].

\section{Sintesis Ag nanopartikel kitosan}

Kitosan dilarutkan dengan $100 \mathrm{ml}$ asam asetat $1 \%$. Kemudian ditambahkan larutan perak nitrat, kemudian diaduk menggunakan magnetic stirrer selama 1 jam pada suhu $80^{\circ} \mathrm{C}$. Tahapan selanjutnya adalah pengukuran panjang gelombang maksimum dengan spektrofotometer (UV-Vis). Proses pengeringan dilakukan dengan alat freeze dryer untuk memperoleh nanopartikel perak kitosan yang stabil.

\section{Karakterisasi Ag nanopartikel}

Analisis Spektrofotometer UV-Vis

Sebanyak $5 \mathrm{ml}$ sampel dimasukkan dalam kuvet lalu diukur panjang gelombangnya menggunakan alat Spektrofotometer UV-Vis dengan menggunakan blangko etanol. Pengukuran juga dilakukan terhadap larutan AgNO3 1000 ppm sebagai pembanding.

\section{Analisis Fourier Transform Infrared Spectroscopy (FTIR)}

Sampel yang telah di freeze drying dihaluskan terlebih dahulu lalu diambil $2 \mathrm{mg}$ dicampur dengan $100 \mathrm{mg} \mathrm{KBr}$ untuk dibuat pelet dengan pencetak vakum. Pelet yang terbentuk dikenai sinar infra merah dengan jangkauan bilangan gelombang 4.000-400 $\mathrm{cm}^{-1}$. Latar belakang absorpsi dihilangkan dengan cara pelet $\mathrm{KBr}$ dijadikan satu pada setiap pengukuran. Pengukuran juga dilakukan terhadap serbuk kulit udang yang telah dideproteinasi, kitin, dan kitosan.

\section{Analisis PSA (Particle Size Analyzer)}

Sebelum pengukuran sampel, aquadest dimasukkan ke dalam fluid tank sebagai baseline. Sampel dimasukkan ke dalam fluid tank tetes demi tetes hingga konsentrasi mencukupi. Distribusi ukuran dalam sampel akan terukur melalui grafik yang dihasilkan.

\section{Analisis SEM (Scanning Electron Microscope)}

Sampel hasil freeze drying diamati morfologinya menggunakan SEM dengan cara sampel diletakkan pada plat aluminium yang memiliki dua sisi, kemudian dilapisi dengan lapisan emas setebal $100 \mathrm{~nm}$ dengan waktu coating \pm 30 detik. Sampel yang telah dilapisi lalu diamati dengan menggunakan alat SEM (Scanning Electron Microscope).

\section{Hasil dan Pembahasan}

Pada penelitian ini, dilakukan sintesis nano partikel perak dengan kitosan sebagai agen pereduksi dan penstabil.

\section{Sintesis Kitosan dari cangkang Udang}

Sintesis kitosan dilakukan dengan cara menghilangkan gugus asetil (deasetilasi) dari kitin menggunakan larutan basa $\mathrm{NaOH}$ dengan konsentrasi $50 \%(\mathrm{~b} / \mathrm{v})$. Pada deasetilasi terjadi pemutusan ikatan antara karbon pada gugus asil, dengan nitrogen pada kitin, menjadi gugus amina. Deasetilasi terjadi berdasarkan reaksi hidrolisis kitin dengan basa kuat. Pada penelitian ini diperoleh kitosan dengan derajat deasetilasi $85 \%$.

\section{Sintesis nanopartikel perak}

Sintesis nanopartikel perak dilakukan dengan cara mereduksi ion perak menjadi nanopartikel perak dengan bioreduktor kitosan sebagai agen pereduksi. Terlebih dahulu dibuat larutan induk $\mathrm{AgNO}_{3}$. Kitosan dibuat seri konsentrasi. Kedalam masing-masing erlenmeyer ditambahkan larutan $\mathrm{AgNO}_{3}$, lalu diaduk dengan magnetic stirrer selama 1 jam. Adanya perubahan warna dari bening menjadi coklat-kekuningan dan/atau gelap menunjukkan adanya pembentukan nanopartikel perak. 
Tabel 1. Uji Karakteristik Kitosan

\begin{tabular}{lcc}
\hline \multicolumn{1}{c}{ Parameter } & Standar (SI) & Hasil \\
\hline Rendamen & - & \\
-Kitin & - & \\
-Kitosan & Butiran atau & \\
\hline \multicolumn{3}{c}{ serpihan } \\
Morfologi partikel & $>70 \%$ & Butiran \\
\hline $\begin{array}{l}\text { DD (Derajat } \\
\text { deasetilasi) }\end{array}$ & & \\
\hline Sumber: Data Primer, 2014 &
\end{tabular}

Berdasarkan penelitian sebelumnya mengenai Nanopartikel Emas dan Perak dari Trianthema decandra: Sintesis, Karakterisasi, dan Sifat Antimikroba, perubahan warna menjadi abu-abu gelap dijadikan indikator untuk menunjukkan terbentuknya nanopartikel perak. Perubahan warna juga dijadikan indikator. Dalam penelitian tersebut, campuran berubah warna menjadi coklat kemerahan setelah disimpan selama 72 jam. Perubahan warna terjadi karena eksitasi dari surface Plasmon resonance dalam nanopartikel perak [1, $4,6]$.

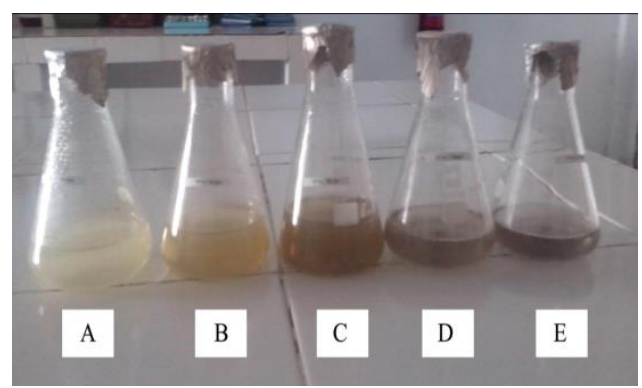

Gambar 1. Larutan Nano partikel Ag

Karakterisasi nanopartikel perak

Reduksi ion perak menjadi nanopartikel perak diamati dengan mengukur spektrum ultraviolet-visible larutan tersebut menggunakan spektrofotometer UV-Vis (Shimadzu) yang dioperasikan pada range 200-500 nm. Dilakukan juga pengukuran terhadap larutan $\mathrm{AgNO}_{3}$ sebagai pembanding. Dari hasil pengukuran panjang gelombang maksimum menggunakan spektrofotometer UV-Vis didapatkan panjang gelombang maksimum $421,60 \mathrm{~nm}$.

Berdasarkan beberapa hasil penelitian sebelumnya mengenai sintesis nanopartikel perak, panjang gelombang $\geq 400 \mathrm{~nm}$ dapat mengindikasikan keberadaan nanopartikel perak dalam larutan. Ukuran partikel dianalisis menggunakan Particle Size Analyzer (PSA). Pengukuran dilakukan terhadap larutan sampel, dimana kitosan digunakan untuk mereduksi larutan perak nitrat. Sampel ini dipilih karena panjang gelombang maksimumnya yaitu 421,60 nm dan absorbansinya sebesar 0,362 (paling besar) Tabel 2.

Tabel 2. Hasil analisis Particle Size Analyzer (PSA)

\begin{tabular}{cccccc}
\hline No & Metode & $\begin{array}{l}\text { Dv10 } \\
(\mathrm{nm})\end{array}$ & $\begin{array}{c}\text { Dv50 } \\
(\mathrm{nm})\end{array}$ & $\begin{array}{c}\text { Dv90 } \\
(\mathrm{nm}) ;\end{array}$ & $\begin{array}{c}\text { Ukuran } \\
\text { rata- } \\
\text { rata } \\
(\mathrm{nm})\end{array}$ \\
\hline 1 & Cumulants & 81,30 & 147,95 & 291,91 & 154,07 \\
\hline
\end{tabular}

Sampel yang disintesis berdasarkan analisis spektrofotometri UV-Vis memiliki panjang gelombang maksimum 421,60 nm. Setelah dianalisis dengan Particle Size Analyzer memiliki rata-rata ukuran partikel yaitu 154,07 $\mathrm{nm}$, dimana rentang ukuran partikel yaitu 40,75 nm sampai dengan $589,00 \mathrm{~nm}$.

Dalam penelitian ini, dilakukan analisis FTIR terhadap empat jenis sampel, yaitu serbuk kulit udang yang telah dihilangkan kandungan proteinnya (Gambar 2), kitin (Gambar 3), kitosan (Gambar 4), dan nanopartikel perak (Gambar 6). Pada analisis FTIR pada kulit udang yang telah dihilangkan kandungan proteinnya dengan menambahkan $\mathrm{NaOH} 1 \mathrm{M}$ menunjukkan beberapa puncak absorbansi, terdapat puncak yang terletak pada bilangan gelombang $3446,79 \mathrm{~cm}^{-1}$ yang menunjukkan adanya gugus -OH. Puncak absorbansi pada bilangan gelombang $3275,13 \mathrm{~cm}^{-1}, 3109,25 \mathrm{~cm}^{-1}$, 2958,60 cm-1, 2927,94 cm-1, dan $2885 \mathrm{~cm}^{-1}$ menunjukkan adanya gugus $-\mathrm{CH}$. Puncak pada bilangan gelombang 1795,73 cm $\mathrm{cm}^{-1}$, menunjukkan gugus fungsi $\mathrm{C}=\mathrm{O}$. Terdapat puncak absorbansi pada bilangan gelombang $1654,92 \mathrm{~cm}^{-1}$ yang menunjukkan gugus $-\mathrm{NH}$ atau $-\mathrm{NHCOCH}_{3}$ (karbonil amida). Gugus $-\mathrm{CN}$ ditunjukkan dengan adanya puncak absorbansi $1315,45 \mathrm{~cm}^{-1}, 1261,45 \mathrm{~cm}^{-1}, 1203,58 \mathrm{~cm}^{-1}, 1068 \mathrm{~cm}^{-}$ 1 , dan $1029 \mathrm{~cm}^{-1}$.

Adapun analisis FTIR terhadap kitin (Gambar 3) menunjukkan beberapa puncak absorbansi, pada bilangan gelombang 3500,80 
$\mathrm{cm}^{-1}$ menunjukkan gugus -OH. Terdapat beberapa puncak absorbansi karbonil amida $\mathrm{NHCOCH}_{3}$ yang merupakan salah satu gugus fungsi yang dominan pada kitin, yaitu pada bilangan gelombang 3257,77 $\mathrm{cm}^{-1}, 1664,57 \mathrm{~cm}^{-1}$, dan pada $1315,45 \mathrm{~cm}^{-1}$. Puncak absorbansi pada $2960,73 \mathrm{~cm}^{-1}$ menunjukkan adanya gugus $-\mathrm{CH}_{3}$.

Analisis Kitosan dengan instrumen FTIR (Gambar 4) diperoleh beberapa puncak absorbansi, pada bilangan gelombang 3446,79 $\mathrm{cm}^{-1}$, menunjukkan adanya gugus $-\mathrm{OH}$ dengan intensitas kuat. Puncak absorbansi pada bilangan gelombang 1651,07 $\mathrm{cm}^{-1}$ dan 1597,06 $\mathrm{cm}^{-1}$, menunjukkan adanya gugus $-\mathrm{NH}_{2}$. Adapun beberapa gugus fungsi lain yaitu pada puncak absorbansi 2879,72 $\mathrm{cm}^{-1}$ yaitu C-H, gugus $\mathrm{CH}_{2}$ pada bilangan gelombang 1340,53 $\mathrm{cm}^{-1}$, C-O pada bilangan gelombang $1153,43 \mathrm{~cm}$ 1 dan 1080,14 $\mathrm{cm}^{-1}$. Puncak absorbansi pada bilangan gelombang 1033,85 $\mathrm{cm}^{-1}$ menunjukkan gugus fungsi C-N. Pada kitosan, gugus karbonil amida $\left(\mathrm{NHCOCH}_{3}\right)$ pada bilangan gelombang $1651,07 \mathrm{~cm}^{-1}$, intensitasnya menurun dibandingkan dengan dengan kitin karena telah terhidrolisis oleh bantuan basa kuat $\mathrm{NaOH} 50 \%$ $(\mathrm{b} / \mathrm{v})$ menjadi gugus amina.

Hasil analisis FTIR setelah sintesis Perak yaitu puncak absorbansi pada bilangan gelombang $3442,94 \mathrm{~cm}^{-1}$ menunjukkan gugus $\mathrm{OH}$ dimana intensitasnya menjadi lebih rendah dibandingkan dengan kitosan. Puncak absorbansi pada bilangan gelombang 1560,41 $\mathrm{cm}^{-1}$ menunjukkan gugus $\mathrm{C}=\mathrm{C}$ aromatik. Gugus amin C-N ditunjukkan oleh puncak absorbansi pada bilangan gelombang $1068,56 \mathrm{~cm}^{-1}$ dan $1022,27 \mathrm{~cm}^{-1}$. Tidak ditemukan gugus $-\mathrm{NH}_{2}$ pada nanopartikel perak. Untuk Karakterisasi morfologi, dilakukan analisis dengan menggunakan SEM.

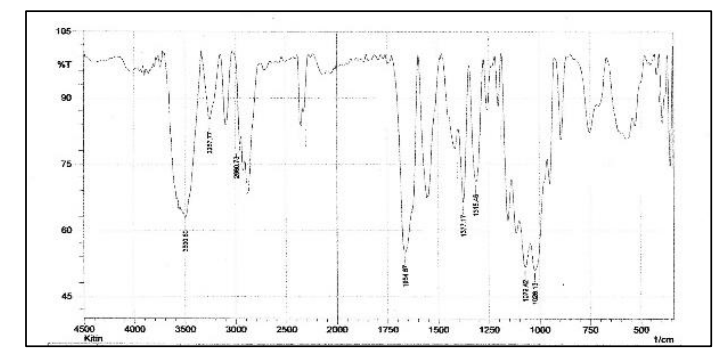

Gambar 2. Spektrum FTIR serbuk kulit udang yang telah dideproteinasi

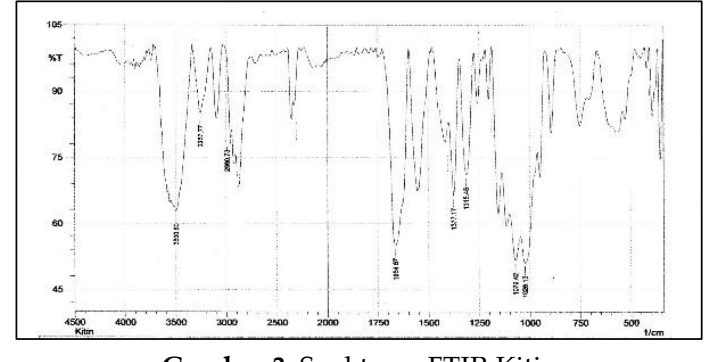

Gambar 3. Spektrum FTIR Kitin

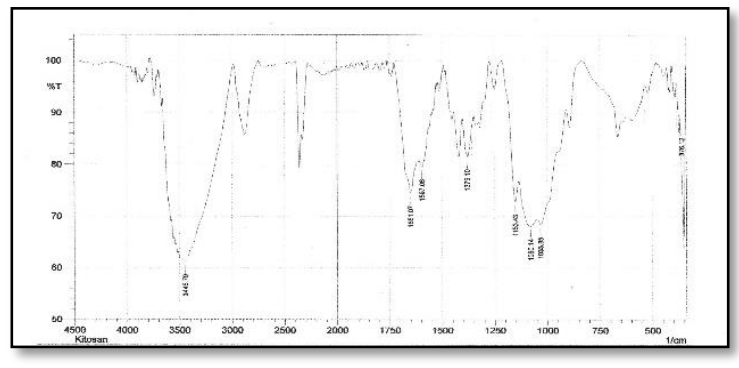

Gambar 4. Spektrum FTIR Kitosan

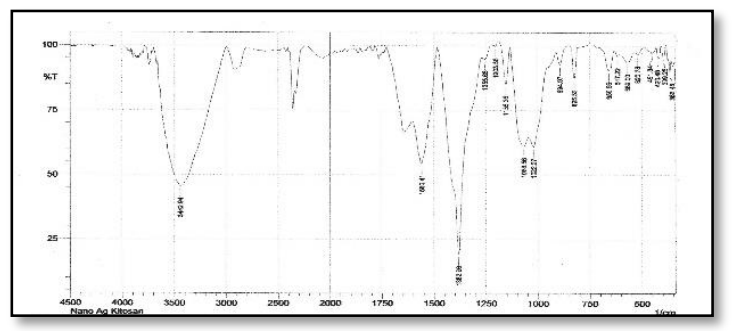

Gambar 5. Spektrum FTIR Ag Nanopartikel
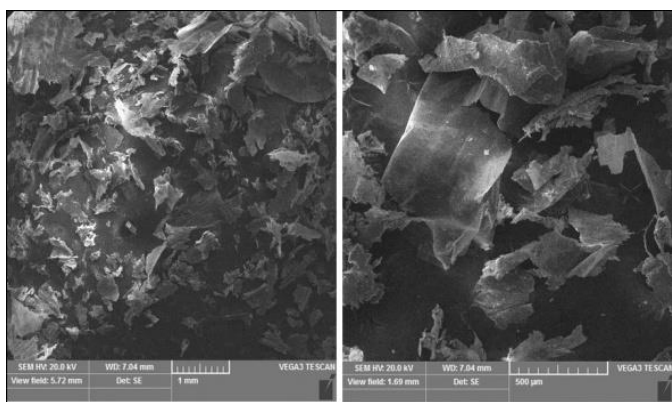

Gambar 6. Morfologi sampel, tampak lapisan tipis yang berasal dari kitosan

Morfologi sampel setelah diamati menggunakan instrumen SEM pada gambar 6 menunjukkan bahwa secara umum bentuk sampel adalah serpihan atau lembaran. Pada perbesaran selanjutnya, ditemukan adanya partikel-partikel berwarna terang, yang secara umum berbentuk seperti bulatan. Partikelpartikel yang memiliki ukuran yang bervariasi tersebut menunjukkan adanya unsur perak yang merupakan hasil reduksi dari ion perak 
dalam larutan $\mathrm{AgNO}_{3}$. Ukuran yang tidak seragam kemungkinan besar terjadi akibat adanya agregasi pertikel-partikel perak. Untuk mengatasi agregasi, dapat dilakukan penambahan material atau molekul pelapis partikel.

\section{Kesimpulan}

Berdasarkan hasil penelitian dan pembahasan di atas, dapat disimpulkan bahwa Kitosan dapat disintesis dari Cangakang Udang ditandai dengan adanya gugus pada bilangan gelombang $3446,79 \mathrm{~cm}^{-1}$, menunjukkan adanya gugus $-\mathrm{OH}$ dengan intensitas kuat. Puncak absorbansi pada bilangan gelombang 1651,07 $\mathrm{cm}^{-1}$ dan 1597,06 $\mathrm{cm}^{-1}$, menunjukkan adanya gugus $-\mathrm{NH}_{2}$. Adapun beberapa gugus fungsi lain yaitu pada puncak absorbansi $2879,72 \mathrm{~cm}^{-1}$ yaitu $\mathrm{C}-\mathrm{H}$, gugus $\mathrm{CH}_{2}$ pada bilangan gelombang $1340,53 \mathrm{~cm}^{-1}$, C-O pada bilangan gelombang 1153,43 $\mathrm{cm}^{-1}$ dan 1080,14 $\mathrm{cm}^{-1}$. Puncak absorbansi pada bilangan gelombang $1033,85 \mathrm{~cm}^{-1}$ menunjukkan gugus fungsi C-N. Pada kitosan, gugus karbonil amida $\left(\mathrm{NHCOCH}_{3}\right)$. Pengukuran dengan Particle Size Analyzer (PSA), ukuran rata-rata partikel Perak yaitu $154,07 \mathrm{~nm}$.

\section{Daftar Pustaka}

1. Marzuki, Q., Pemanfaatan Limbah Kulit Udang Windu (Penaeus monodon) Sebagai Edible Coating dan Pengaruhnya Terhadap Kadar Ion Logam $\mathrm{Pb}$ (II) pada Buah Stoberi (Fragaria $x$ ananassa). Chem Info Journal 2013, 1, (1), 232-239.

2. Vo-Dinh, T., Nanotechnology in biology and medicine: methods, devices, and applications. CRC Press: 2007.

3. Tibbals, H. F., Medical nanotechnology and nanomedicine. CRC Press: 2010.

4. Geethalakshmi, R.; Sarada, D., Gold and silver nanoparticles from Trianthema decandra: synthesis, characterization, and antimicrobial properties. International journal of nanomedicine 2012, 7, 5375.

5. Baskaralingam, V.; Sargunar, C. G.; Lin, Y. C.; Chen, J. C., Green synthesis of silver nanoparticles through Calotropis gigantea leaf extracts and evaluation of antibacterial activity against Vibrio alginolyticus. Nanotechnology development 2012, 2, (1), e3e3.

6. Thilagam, M.; Tamilselvi, A.; $\begin{array}{lll}\text { Chandrasekeran, } & \text { B.; Rose, }\end{array}$
Phytosynthesis of silver nanoparticles using medicinal and dye yielding plant of Bixa orellana L. leaf extract. J Pharma Sci Innov 2013, 2, 9-13.

7. Adlim, A.; Bakar, M. A., Preparation of chitosan-gold nanoparticles: part 1 (of 2). Effect of reducing technique. Indonesian Journal of Chemistry 2008, 8, (2), 184-188.

8. Hargono, H.; Abdullah, A.; Sumantri, I., Pembuatan kitosan dari limbah cangkang udang serta aplikasinya dalam mereduksi kolesterol lemak kambing. Reaktor 2008, 12, (1), 53-57. 